\title{
Factors Influencing Technical Efficiency of Paddy Farms in Mullaitivu District: Non - Parametric Approach
}

\author{
A. $\operatorname{Thayaparan}^{1} \&$ N. Neruja ${ }^{2}$ \\ ${ }^{1,2}$ Department of Economics and Management \\ Vavuniya Campus \\ SRI LANKA \\ aruppillaithayaparan@yahoo.com ${ }^{1} \& \underline{\text { n.neruja92@gmail.com }}{ }^{2}$
}

\begin{abstract}
Technical efficiency means the effectiveness which a given set of inputs used to produce a given output and it helps to produce the maximum output using minimum quantity of inputs for any firm or farm products. The objectives of this study are to estimate the Hicks - Moorsteen index and examine the impact of demographic, economic, farming and environmental characteristics on total factor productive efficiency index. Further, this study evaluate the overall performance of paddy farmers $(n=200)$ and identify the factors affecting the efficiency using two - stage Data Envelopment Analysis (DEA) during 2019/2020 period in Mullaitivu district of Sri Lanka. Hicks - Moorsteen index showed that among the components of the index, $94 \%$ of the highest mean value was attained in Input Oriented Technical Efficiency (ITE) followed by $93 \%$ of efficiency was attained in Output Oriented Scale Efficiency (OSE). Tobit regression results suggested that education, availability of training and destroy the crops whether the crops were damaged by environmental factors were significantly affecting the Hicks - Moorsteen index. Further, results of two - stage input-oriented DEA revealed that on average the overall technical efficiency of paddy farms was nearly $42 \%$, scale efficiency was nearly $45 \%$ and variable returns to scale technical efficiency was nearly $93 \%$. The Tobit regression results showed that, education, land ownership, amount of savings, loan size, land quality and farm income were positively impact on overall technical efficiency while experience, ownership of land, amount of savings and destroy the crops whether the crops were damaged by environmental factors significantly affected on technical efficiency. Conversely, scale efficiency of paddy farming mostly influenced by education, land ownership, saving amount, loan size, quality of land and farm. The paper concludes that both input oriented technical efficiency and output oriented scale efficiency need to be improved further as well as scale efficiency mostly affected by economic and farming characteristics in the study.
\end{abstract}

Keywords:- Farming characteristics, Hicks - Moorsteen index, Scale efficiency, Tobit regression, Two - stage data envelopment analysis. 


\section{INTRODUCTION}

Agriculture sector plays a vital role in the Sri Lankan. In 2019, the average contribution of this sector to countries Gross Domestic Product (GDP) was 7.42 percent, and also provides 23.73 percent of the employment to the countries workforce. During recent decades agriculture has experienced major gains in productivity however, the rate of increase has slowed down in developing countries including Sri Lanka in recent years. Paddy productivity in Sri Lanka was 4 to 5 tons per hectare from 2005 to 2009. Year by year, it has steadily declined. Furthermore, it was 5 tons per hectare from 2009 to 2015, and 3.4 tons per hectare from 2015 to 2019 (Department of Censes Statistics report, 2019). Among the agriculture sector, paddy sector in Sri Lanka playing a major role in terms of supplying food requirement and contributes to the GDP and provides employment opportunities. To increase the efficiency in agriculture sector including paddy sector is the way to upgrade the sector which enhance the living standards of the rural people in Sri Lanka. In this background, this study aims to identify the technical efficiency and its determinants of paddy cultivation in Mullaitivu district. Paddy production sector is a main sector, which gives lower productivity and lower income to the people. Significant new laws and policies have been introduced in the past and present to achieve paddy self-sufficiency and increase farmers' profits. Sri Lanka has recently been able to approach self-sufficiency, but has struggled to meet the satisfaction of poor farmers, whose quality of living has deteriorated. Sri Lankan agriculture faces a significant challenge if it is to boost economic performance and living standards through productivity growth in rural area.

In contrast to other districts in the north, Mullaitivu is considered one of the more prosperous districts (Statistical Hand Book, Mullaitivu, 2019). The majority of people in Mullaitivu district live below the poverty line Furthermore, agriculture is the primary source of income for the vast majority of rural people in the Mullaitivu district. Farming is the primary occupation of more than 61 percent of all families. Around 23,737 farm families are directly involved in paddy farming at the present time, and the district has $17,320 \mathrm{Ha}$ of suitable land for paddy cultivation. (Department of Agriculture report, Mullaitivu, 2020). Unfortunately, the majority of the farmers are small landowners with less than 0.405 $\mathrm{Ha}$ of land, and they often face income insecurity from farming, leading to extreme poverty among the farmers and a reduction in their living standards in the study area. An increase in the productivity of paddy farming may be significant not only to get 
a better harvest but also to improve the standard of living of employees in paddy farming. This objective can be achieved by improving the technical and allocative efficiencies of paddy farmers which provides an opportunity to produce the maximum harvest without an increase in inputs. Based on these facts, the research problem of this study can be stated in the following manner: how do we improve the technical efficiency of paddy farmers in Sri Lanka in order to increase the paddy production? This study is based on this main question. Against this backdrop, the aim of this study is to analyse and empirically determine the technical and allocative efficiencies of paddy farmers in major paddy growing areas in Mullaitivu.

\subsection{Objectives of the study}

This study focused on the following objectives.

$\checkmark$ To estimate the various components of HicksMoorsteen total factor productivity index of paddy farms in Mullaitivu district.

$\checkmark$ To identify the impact of demographic, economic, farming and environmental characteristics on HicksMoorsteen total factor productivity index of paddy farms.

To evaluate the overall performance of paddy farms using two stage input-oriented data envelopment analysis in the study.

To examine the factors which affecting the variable returns to scale technical efficiency of paddy farms in the study.

\subsection{Review of literature}

There are number of studies done by other researchers on technical efficiency of various crops using different methods in different countries. Most of the studies on determinants of technical efficiency of paddy and other vegetable crops done by Sri Lankan researchers using stochastic frontier approach and Translog production frontier method and they are a lack of studies on Hicks - Moorsteen index and Two-Stage DEA in paddy production. Therefore, this study seeks to investigate the factors Influencing Technical Efficiency among paddy farmers at their farm level and fill the research gap using Hicks Moorsteen index and Two-Stage DEA in Mullaitivu district.

Nugawela (2019) analysed Sri Lanka's total factor productivity 
change during conflict and postconflict periods using Solow's Residual model and an Index number approach (HicksMoorsteen Total Factor Productivity Index). Finding of both approaches reveal that the TFP growth during the conflict period was higher than that of the post-conflict period. Based on the decomposition of HMTFPI into Technological Change (TC) and Efficiency Change (EC) indices, it was revealed that the main source of TFP change throughout the sample period is TC. EC had been negative throughout the sample period.

A parametric approach was utilized by Shantha et al (2013) have examine the technical efficiency of paddy farming under major irrigation conditions in the dry zone of Sri Lanka. The empirical study was carried based on a sample of 357 paddy farmers under Nagadeepa reservoir and the results of average technical efficiency of selected farmers given by the Translog model is 72.80 percent. This indicates that there is scope of further increasing the output by 27.2 percent without increasing the level of input.

Peng et al (2020) used the HicksMoorsteen total factor productivity index method, the study indicates the total factor productivity of cultivated land use CL-TFP presents a fluctuating upward trend and reaches data envelopment analysis (DEA) efficiency during the sample period. The regional results reveal a significant spatial difference, especially in the midwest region, which fails to reach DEA efficiency. China's main cultivated land did not realize economies of scale.

Linh et al (2017) to identify the factors influencing efficiency using two-stage DEA approach. Estimated results in the first stage of DEA showed that the farmers achieved relatively high overall technical efficiency and scale efficiency score ( 0.801 and 0.966 , respectively). Most of the rice producers operated their farms at decreasing returns to scale. The study also indicated positive impacts of education on technical efficiency while other factors including credit access, training and rice cultivated area showed negative influences on the rice farm efficiency. This result suggests that the policy makers should pay more attentions on technical training and credit programs for the farmers to increase their technical efficiency in rice production.

Estimation of technical efficiency in the Translog stochastic production frontier model with an application to oil palm produce mills industry in Nigeria were analysed by Amaechi et al (2014). They used a multi stage sampling method to select 30 mills in the study area and their 
estimated technical efficiency results showed that, firm level technical efficiency means of 70.62 varies with the range of $37.42 \%$ to $93.46 \%$. This wide variation in oil farm output of millers from the frontier model found that those differences management practices of millers than random variability. In addition, their study implies that education, processing experience, membership of cooperative society, credit, fruits petroleum energy and water are the major determinants of technical efficiency (Khaile ,2012). Results on the second stage of the twostage DEA model revealed a mean quality efficiency of $97 \%$ for small-scale farmers when benchmarked against each other. The results indicate that smallscale farmers have the potential to increase their mean efficiency by three percentage points to operate on the quality efficient frontier when benchmarked against each other. A benchmark of both small-scale and largescale raise in producers revealed a mean quality efficiency of $79 \%$ and $88 \%$ respectively. The scope of variations between the quality efficiency scores of small-scale farmers was recognized to be limited.

However, the most of the researches have been done using different non parametric index in worldwide, it is very little bit in Sri Lanka especially in Mullaitivu District. The absence of quantitative research on technical efficiency on paddy farming is one of the main problems for policy makers in decision making, consequently, it seems that there is a gap in the theoretical knowledge and quantities measurement of technical efficiency of paddy farm in Sri Lanka.

\section{METHODS}

This section covers the study area, sources of data collection and the method of techniques which are employed in the study.

\subsection{Study area}

Mullaitivu district is one of the major paddy cultivating districts in Sri Lanka in Northern Province under dry zone. The district has $17320 \mathrm{Ha}$ of cultivable lands for paddy cultivation which is the major income earning source of the rural people. To estimate the total factor productive efficiency and identify the factors determine the different efficiency components, Hicks - Moorsteen total factor productive index and two stage DEA approach were used in the study. For the purpose of these data analysis Maritimepattu DS division in the district was selected and using multistage sampling method, six villages were taken as the study area. From each village, 20 farmers were selected randomly and finally 120 farmers were selected in the study. The output and inputs data on paddy farming in terms of quantities and in expenditures were collected 
through a questionnaire for the period 2019/2020.

\subsection{Method of data collection}

The study mainly used the primary data which was collected with the aid of pretested semistructured questionnaire from cross sections of paddy farmers in the study area. A questionnaire based survey was conducted during 2019/2020 production season to collect the relevant data from the paddy farmers in the selected study area. The collected data were used to estimate the total factor productive efficiency using Hicks - Moorsteen index and two - stage input-oriented data envelopment (DEA) approach also applied to estimate the technical efficiency levels under CRS, VRS and scale efficiency of paddy farms in the study. To identify the impact of demographic, economic, farming and environmental characters on Hicks - Moorsteen index and on variable returns to scale technical efficiency, Tobit regression model was estimated.

\subsection{Methods of data analysis}

This study used non - parametric approach focusing on Hicks Moorsteen total factor productivity index and two stage data envelopment analysis to estimate the decompositions of technical efficiency and its determinants of paddy farmers in the study.

\subsubsection{Hicks - Moorsteen total factor productivity index}

To overcome the deficiency in the Malmquist index, Hicks Moorsteen Total Factor Productivity Index (HMTFPI) was used. It can be defined as the ratio of growth in outputs to growth in inputs (Diewert, 1992), where growth in outputs and inputs are measured through index numbers.

$$
H M T F P I=\frac{\text { Growth in output }}{\text { Growth in inputs }}
$$

Bjurek (1996) re-introduced a modified approach of calculating the existing Hicks-Moorsteen Total Factor Productivity Index (HMTFPI) as a ratio of Malmquist output and input indices.

$$
\begin{aligned}
& \text { HMTFPI } \\
& =\frac{\text { Malmquist output index }}{\text { Malmquist input index }}
\end{aligned}
$$

Once growth in inputs and outputs are measured through an appropriate index (among any available indices), measuring change in productivity through HMTFPI is easy, and it also provides the source of change (whether it is technological change or efficiency change) (Nemoto and Goto, 2005). Accordingly, the decomposition of HMTFPI in to TC and EC 
component indices can be presented as:

$$
\begin{gathered}
\text { HMTFPI }=\frac{M_{0}\left(y_{t}, y_{t+1}, x_{t}, x_{t}\right)}{M_{0}\left(y_{t}, y_{t+1}, x_{t}, x_{t}\right)} \\
=\left(\frac{\left(D_{0}^{t}\left(y_{t+1}, x_{t+1}\right)\right.}{\left(D_{0}^{t+1}\left(y_{t+1}, x_{t+1}\right)\right.} \times \frac{D_{0}^{t}\left(y_{t}, x_{t}\right)}{D_{0}^{t+1}\left(y_{t}, x_{t}\right)}\right)^{\frac{1}{2}} \\
\times\left(\frac{D_{0}^{t+1}\left(y_{t}, x_{t}\right)}{D_{0}^{t}\left(y_{t}, x_{t}\right)}\right)
\end{gathered}
$$

Where, $T c=\left(\left(\frac{D_{0}^{t}\left(y_{t+1}, x_{t+1}\right)}{D_{0}^{t}\left(y_{t}, x_{t}\right)}\right) \times\right.$

Dotyt,xtDotyt, xt12 and

$$
E c=\left(\frac{D_{0}^{t+1}\left(y_{t+1}, x_{t+1}\right)}{D_{0}^{T}\left(y_{t}, x_{t}\right)}\right)
$$

A value of a component index greater than 1 indicates improvement, while a value less than 1 indicates deterioration of the conditions. Further, in the absence of panel data, the HMTFPI is preferred over the Malmquist index, as the Malmquist approach uses the concept of cone technology, which requires a dataset large enough to provide a good description of the underlying technology (Coelli et al., 2005). Decomposition of Productivity Index Numbers (DPIN) software has been used to compute the HMTFPI and its components in the data analysis.

\subsubsection{Two - Stage of Data Envelopment Analysis}

Data Envelopment Analysis (DEA) method was used in this study to obtain efficiency scores of paddy production in Mullaitivu of Sri Lanka. DEA was solely used for the analysis of TE because it has the capability to integrate technical parameters that might not be captured by parametric production efficiency techniques and its ability of tackling multiple inputs and outputs (Coelli et al., 2005). The efficiency of a firm is calculated based on the DMUs' observed best practice (Coelli et al., 2005). Those DMUs lying on the frontier, with a score of 1 are considered as efficient relative to the rest of the samples, whereas those lying below the frontier, with a score of less than 1 are classified as inefficient. All efficiency scores in DEA fall within 0 and 1 . Inefficiency level of a DMU is determined by how far this DMU is from the frontier. The further away from the frontier the DMU is, the less efficient it is. DEA essentially measures the excessive use of resources for a given level of output (input orientated) or possible increase in output for an assumed level of resources (output orientated). According to Coelli et al.(2005) both output and input orientated models recognize the same group of efficient and inefficient DMU. Also, as the DEA approach does not acknowledge statistical complications such as simultaneous equation bias, the selection of particular orientation is not as critical as opposed to econometric techniques. Argued 
by Coelli et al. (2005) that selection of any particular orientation should be based on the quantities over which the farmer has utmost control. Inputoriented method is adopted to calculate TE in this study. This technique is selected because in agricultural production farmers have more control on their inputs than output (Coelli et al., 2005). This study applied the two-stage DEA to estimate technical efficiency for paddy farmers and identify factors associated with efficiency scores. The DEA approach was widely chosen for efficiency measurements because requirements related to assumptions in the form of production function and distribution of inefficiency terms are not compulsory requirements when applying this approach compare to the one-stage DEA, one sophisticated feature of the two-stage approach is that it takes into account the influence of exogenous variables on efficiency.

In the first stage, the DEA model under the assumption of inputoriented variable returns to scale was adopted to estimate overall and pure technical efficiency and scale efficiency scores. The model is specified as follows.

Subject to,

$$
T E_{V R S}=\min \theta
$$

$$
y \lambda-y t=0,
$$

$$
\begin{gathered}
\theta x_{i}-x \boldsymbol{\lambda} \geq \mathbf{0} \\
N 1^{\prime} \boldsymbol{\lambda}=\mathbf{1} \\
\boldsymbol{\lambda} \geq \mathbf{0}
\end{gathered}
$$

Where, Y and X represent output and input vectors respectively; $\theta$ denotes a scalar and $\lambda$ is an $\mathrm{n} x 1$ vector ofconstants. The value varies from 0 to 1 . A farm is full efficient when reaching technical efficiency score one. While inefficient farm has efficiency score lower than one scale efficiency (SE) of farms can be formulated by dividing CRS TE by VRS TE. In which, technical efficiency under CRS can be acquired by removing the convexity constraint $\left(\mathrm{N}_{1^{\prime}}{ }^{\prime} \lambda=1\right)$ in the above equation. Then scale efficiency can be specified as follows;

$$
S E=\frac{T E_{C R S}}{T E_{Y R S}}
$$

In the second stage, the explanatory variables were regressed to efficiency scores obtained in the first stage DEA. Tobit regression model was popularly applied in this stage because efficiency scores estimated in the first stage ranged from zero to one and have censored distributions. The model is defined as follows:

$$
\begin{aligned}
& Y_{i}^{*}=x_{i} \beta_{i}+\mu_{i} \quad i \\
& =1,2, \ldots \ldots \ldots n \\
& Y_{i}=y_{i}^{*} \text { if } y_{i}^{*}<0
\end{aligned}
$$

Where, $\mu_{i} \sim N\left(0, \sigma^{2}\right), \quad \mathrm{x}_{\mathrm{i}} \quad$ are explanatory variables and $\beta_{i}$ are unknown

parameters; $Y_{i}^{*}$ represents 
latentvariable; and $y$ is the efficiency scores measured in the DEA model.

\subsubsection{Tobit regression model}

Tobit model is employed to analyse the factors that determine the components of technical efficiency in paddy farms. The Tobit model is also known as truncated or censored regression model and be written as technical efficient function as given below:

$$
\begin{aligned}
T E_{i}=\alpha+\beta_{1} x_{1} & +\beta_{2} x_{2}+\beta_{3} x_{3} \\
& +\beta_{4} x_{4}+\beta_{5} x_{5} \\
& +\beta_{6} x_{6}+\beta_{7} x_{7} \\
& +\beta_{8} x_{8}+\beta_{9} x_{9} \\
& +\beta_{10} x_{10} \\
& +\beta_{11} x_{11} \\
& +\beta_{12} x_{12}+\varepsilon_{i}
\end{aligned}
$$

Where, $\quad T E_{i}$ indicates the components technical efficiency, such overall technical efficiency, pure technical efficiency and scale efficiency. $\alpha$ indicates a constant term, $\beta_{1}-\beta_{12}$ indicate the coefficient of independent variables, and $\varepsilon$ indicates an error term which $T E \sim N\left(0, \sigma^{2}\right)$.

\section{RESULTS AND}

\section{DISCUSSION}

Technical efficiency of paddy farm in the study area is measured using two different methods namely, Hicks Moorsteen total factor productivity index and two stage input - oriented DEA approach. The results derived from each method were described in the following sections.

\subsection{Results of Hicks - Moorsteen total factor productivity index}

A part of this study is to estimate the decompositions of Hicks Moorsteen total factor productivity indices and its determinants of paddy sector in Mullaitivu of Sri Lanka. According to the Hicks Moorsteen total factor productivity index method, the study mainly focuses on paddy yield as the output and labour in man days, size of cultivated land, amount of seed usage, fertilizer usage, amount of pesticide, costs of capital and machinery were taken as the major inputs. Table 01 represents the descriptive statistics of the output and inputs variables used in the analysis and according to that, average paddy yield is $18602 \mathrm{Kg}$ per acre with the range of $5040 \mathrm{Kg}$ to $52560 \mathrm{Kg}$ per acre obtained by the farmers during the study period. Among the inputs, average cost of capital is the highest followed by machinery cost has the highest in the sample. Among other inputs measured in units, the average usage of seed and fertilizer are the highest inputs applied by the farmers in the study. 
Table 1: Descriptive statistics of the variables

\begin{tabular}{|l|c|c|c|c|}
\hline \multicolumn{1}{|c|}{ Variables } & Mean & $\begin{array}{c}\text { Standard } \\
\text { deviation }\end{array}$ & Minimum & Maximum \\
\hline $\begin{array}{l}\text { Paddy Yield (Kg per } \\
\text { acre) }\end{array}$ & 18602.40 & 9907.838 & 5040 & 52560 \\
\hline Labour(Man days) & 13.60 & 2.027 & 9 & 20 \\
\hline Land size (acre) & 8.25 & 4.32 & 2 & 22 \\
\hline Amount of seed (Kg) & 1188.00 & 622.034 & 288 & 3168 \\
\hline Fertilizer usage (Kg) & 1131.79 & 647.116 & 320 & 3520 \\
\hline Pesticide uses (Kg) & 2.14 & 0.507 & 1 & 5 \\
Capital cost (Rs) & 19773.75 & 2583.122 & 14250 & 26000 \\
Cost of machinery (Rs) & 12790.42 & 1545.668 & 9750 & 17000 \\
\hline Age (Years) & 42.01 & 9.262 & 25 & 72 \\
Household(Numbers) & 4.13 & 1.27 & 1 & 8 \\
\hline Education (Years) & 7.97 & 2.463 & 1 & 12 \\
\hline Farm experience (Years) & 19.02 & 9.303 & 2 & 50 \\
\hline Farm income (Rs) & 8366.67 & 3543.092 & 3000 & 18000 \\
\hline Amount of saving (Rs) & 1241.67 & 1362.745 & 0 & 6000 \\
\hline Amount of loan (Rs) & 219000.00 & 280397.077 & 0 & 1500000 \\
\hline
\end{tabular}

Source: Estimated by authors, 2019/2020

In addition to the output and inputs, selected demographic and economic characteristics also explained in terms of descriptive statistics. Among the demographic characters, average age of the farmer is 42 years old with the minimum age of 25 and maximum age of 72 which indicates that a typical farmer was within the economically active age group in the study area.
On average, the members of the family are nearly 4 reveals that the household member could offer farm labour to their paddy cultivation and in case of their education, they spend nearly 8 years for it with a maximum year of 12 in the sample. The farmers have nearly 19 years of experience in farming with economic facilities such as, farm income, saving and loan facilities showing that there is a high variability of farm experience 
among the farmers in the study area.

Table 02 presents the estimated means of Hicks - Moorsteen total factor productivity index and its decompositions in the selected 120 paddy farmers in the study area. Among the components of
Hicks - Moorsteen index, 94\% of the highest mean value was attained in ITE followed by $93 \%$ of efficiency was attained in OSE. On average, $56 \%$ of efficiency was recorded in TFPE followed by $59 \%$ of efficiency attained in RISE and ISME.

Table 2: Descriptive statistics of Hicks - Moorsteen indices and its components

\begin{tabular}{|l|l|l|l|l|}
\hline Indices & Minimum & Maximum & Mean & $\begin{array}{l}\text { Standard } \\
\text { deviation }\end{array}$ \\
\hline TFP & 0.3706 & 1.0000 & .821227 & .1683046 \\
\hline TFPE & 0.1907 & 1.0000 & .569827 & .2376987 \\
\hline OTE & 0.4840 & 1.0000 & .861037 & .1411351 \\
\hline ROSE & 0.2146 & 1.0000 & .651733 & .2220861 \\
\hline OSME & 0.2146 & 1.0000 & .651733 & .2220861 \\
\hline ITE & 0.7657 & 1.0000 & .946727 & .0551790 \\
\hline OSE & 0.6222 & 1.0000 & .932136 & .0665788 \\
\hline ISE & 0.4834 & 1.0000 & .845092 & .1299044 \\
\hline RISE & 0.2041 & 1.0000 & .599936 & .2411490 \\
\hline ISME & 0.2041 & 1.0000 & .599936 & .2411490 \\
\hline RME & 0.2352 & 1.0000 & .692735 & .2130906 \\
\hline
\end{tabular}

Source: Estimated by authors using DPIN 2.1.

To examine the impact of selected demographic, farming and environmental factors on total factor productive efficiency (TFPE), Tobit regression was estimated where the TFPE taken as dependent variable in the study. The estimated results of the model are given in Table 03 . 
Thayaparan A, \& Neruja N., Wayamba Journal of Management 12 (1)

Table 3: Determinants of Hicks - Moorsteen total factor productive efficiency index

\begin{tabular}{|l|l|l|l|l|}
\hline Variables & Coefficients & $\begin{array}{l}\text { Standard } \\
\text { error }\end{array}$ & $\mathbf{t}$ - ratio & Significant \\
\hline Education & 1.643 & 0.805 & 2.04 & 0.044 \\
\hline Farm experience & -0.409 & 0.233 & -1.75 & 0.083 \\
\hline Household size & 2.032 & 1.606 & 1.27 & 0.208 \\
\hline Gender & -6.752 & 4.315 & -1.56 & 0.121 \\
\hline $\begin{array}{l}\text { Ownership of } \\
\text { land }\end{array}$ & -4.919 & 4.221 & -1.17 & 0.246 \\
\hline Training & -10.013 & 5.030 & -1.99 & 0.049 \\
\hline $\begin{array}{l}\text { Extension } \\
\text { services }\end{array}$ & 0.439 & 4.145 & 0.11 & 0.916 \\
\hline $\begin{array}{l}\text { Amount of } \\
\text { saving }\end{array}$ & 0.003 & 0.0016 & 1.86 & 0.066 \\
\hline Loan amount & 0.00004 & $7.76 \mathrm{e}-06$ & 1.81 & 0.074 \\
\hline Quality of land & 10.092 & 6.656 & 1.52 & 0.132 \\
\hline Farm income & 0.0014 & 0.0008 & 1.75 & 0.082 \\
\hline Destroy & -8.734 & 4.281 & -2.04 & 0.044 \\
\hline Constant & 40.153 & 13.211 & 3.04 & 0.003 \\
\hline $\begin{array}{l}\text { Number of observations } \\
\text { LR Chi - square }(12)\end{array}$ & 120 & & \\
Probability > Chi - square & 28.46 & & \\
Pseudo R & 0.0047 & & \\
Log likelihood & 0.026 & & \\
\hline Source: Estman & -533.286 & & \\
\hline
\end{tabular}

Source: Estimated by authors using Stata 13.

In the above Table 3, LR Chi square for the model is 28.46 and, significant at $1 \%$ probability levels, implying that the Tobit model is the best fit and appropriate for the specified equation and, the estimated coefficients in the model are different from zero. The variables namely education, training and destroyed the crops were significant whereas farm experience, amount of saving, loan amount and income earns from farming were significant influence on total factor productive efficiency at 5\% and $10 \%$ levels respectively. Rest of other variables were insignificant in the model to determine the 
total factor productive efficiency of paddy farms in the study area. The estimated coefficient for education has positive impact on total factor productive efficiency and it is significant at $5 \%$ probability level implies that educated farmers were more technical efficiency and productive efficiency in the use of their inputs to maximize output than uneducated farmers. The estimated coefficients of farm experience have negative impact on total factor productive efficiency of paddy farming which is statically significant at $10 \%$. Even the farmers have more years of experience in farming, due to their older age and physical conditions, they may be unable to do their farming effectively and thus its efficiency becomes negative in the study. The coefficient of training has

\subsection{Results of two - stage input- oriented DEA approach}

In addition to the Hicks Moorsteen total factor productivity approach, this study also applied DEAP 2.1 program to estimate the technical efficiency of paddy farms using two - stage DEA approach and based on that overall technical efficiency, various returns to scale and scale efficiency scores negative and it is significant at $5 \%$ level shows that even the farmers undergone a training, it not helps to increase their efficiency of paddy farms in the district. The coefficients for amount of saving, loan amount and income from farming have positively influence on total factor productive efficiency with $10 \%$ significant levels. This reveals that farmers have these facilities will be able to procure the required quantity of farm inputs at the right time, thus, enhancing their total factor productivity and efficiency. Destroyed of their paddy by any natural disaster was found to have negative influence on total factor productive efficiency and it was significant at 5\% level. If their paddy yield destroyed by the natural disaster, it will reduce their productivity and efficiency.

were measured in the study. In the beginning, output is the paddy yield and seven inputs such as costs of labour, costs of capital, machinery costs, seed costs, fertilizer costs and pesticide costs with size of land were used to analyse them in terms of mean and standard deviation. The descriptive statistics of the output and inputs depicted in Table 04. 
Table 4: Summary statistics of output and inputs of paddy farms

\begin{tabular}{|l|l|l|l|l|}
\hline \multicolumn{1}{|c|}{ Variables } & \multicolumn{1}{|c|}{ Mean } & \multicolumn{1}{|c|}{$\begin{array}{c}\text { Standard } \\
\text { deviation }\end{array}$} & Minimum & Maximum \\
\hline Output of paddy (Kg per acre) & 18602.40 & 9907.838 & 5040 & 52560 \\
\hline Labour cost (Rs) & 13346.67 & 2747.495 & 8800 & 20000 \\
\hline Cost of capital (Rs) & 19773.75 & 2583.122 & 14250 & 26000 \\
\hline Seed cost (Rs) & 2201.25 & 395.535 & 1700 & 2800 \\
\hline Cost of fertilizer (Rs) & 1219.62 & 216.988 & 875 & 1820 \\
\hline Cost of pesticide (Rs) & 1674.79 & 451.800 & 725 & 3475 \\
Cost of Herbicide(Rs) & 1309.79 & 422.419 & 375 & 2650 \\
Cost of transport (Rs) & 1920.83 & 612.368 & 1000 & 4000 \\
\hline
\end{tabular}

Source: Authors' calculation, 2020.

According to the Table 04, it describes the basic statistics of paddy yield, its inputs and the selected demographic, economic, farming and environmental characteristics used in the efficiency measures. The average paddy production was 18 , $602 \mathrm{Kgs}$ with a range of minimum $5040 \mathrm{Kg}$ up to maximum $52560 \mathrm{Kg}$ in the study area. Labour measured terms of cost which are used as family and hired workers in paddy production activities. All inputs used in the study were measured in rupees except land size and according to that, the mean value for fertilizer cost is 1131.79 which varies from 320 to 3520 . The average size of paddy cultivated land is 8.25 acres with a range of 2 and 22 acres implies that rural farm households were indeed operating with quite larger land holdings in this survey area.

In addition to the descriptive statistics, frequency of selected variables also analysed and its results were given in Table 05.

Table 5: Frequency of selected variables

\begin{tabular}{|l|l|l|}
\hline Variables & Frequency & Percentage \\
\hline Gender & & \\
\hline Male & 60 & 50 \\
\hline Female & 60 & 50 \\
\hline Training & & \\
\hline Yes & 69 & 57.5 \\
\hline No & 51 & 42.5 \\
\hline Extension & & \\
\hline Yes & 55 & 45.8 \\
\hline
\end{tabular}




\begin{tabular}{|l|l|l|}
\hline No & 65 & 54.2 \\
\hline Credit & & \\
\hline Yes & 70 & 58.3 \\
\hline No & 50 & 41.7 \\
\hline Land quality & & \\
\hline Yes & 24 & 20 \\
\hline No the & 96 & 80 \\
\hline $\begin{array}{l}\text { Destroy by } \\
\text { crops } \\
\text { natural disaster }\end{array}$ & 82 & \\
\hline Yes & 38 & 31.7 \\
\hline No & & \\
\hline
\end{tabular}

Source: Authors' calculation, 2020.

The above results suggest that male and female farmers are equal in the sample and $57.5 \%$ of them have training opportunities and rest of them don't have it. $45.8 \%$ of the farmers have opportunities to get extension services where as $54.2 \%$ of them don't have such facilities in the study area. In case of credit facilities, $58 \%$ of them have access to credit while rest of them don't it.

To estimate the technical efficiency of selected paddy farmers in the study area, terms of CRS, VRS and scale efficiency, two stage inputoriented DEA analysis was employed using the computer program DEA 2.1, developed by Coelli et al., (1996). In the beginning, overall technical efficiency (Constant returns to scale) was measured in terms of percentage using pie chart and according to that $59.2 \%$ of the farmers attain less than $40 \%$ efficiency scores while only $10 \%$ of them attained the efficiency scores $81 \%$ and above. 


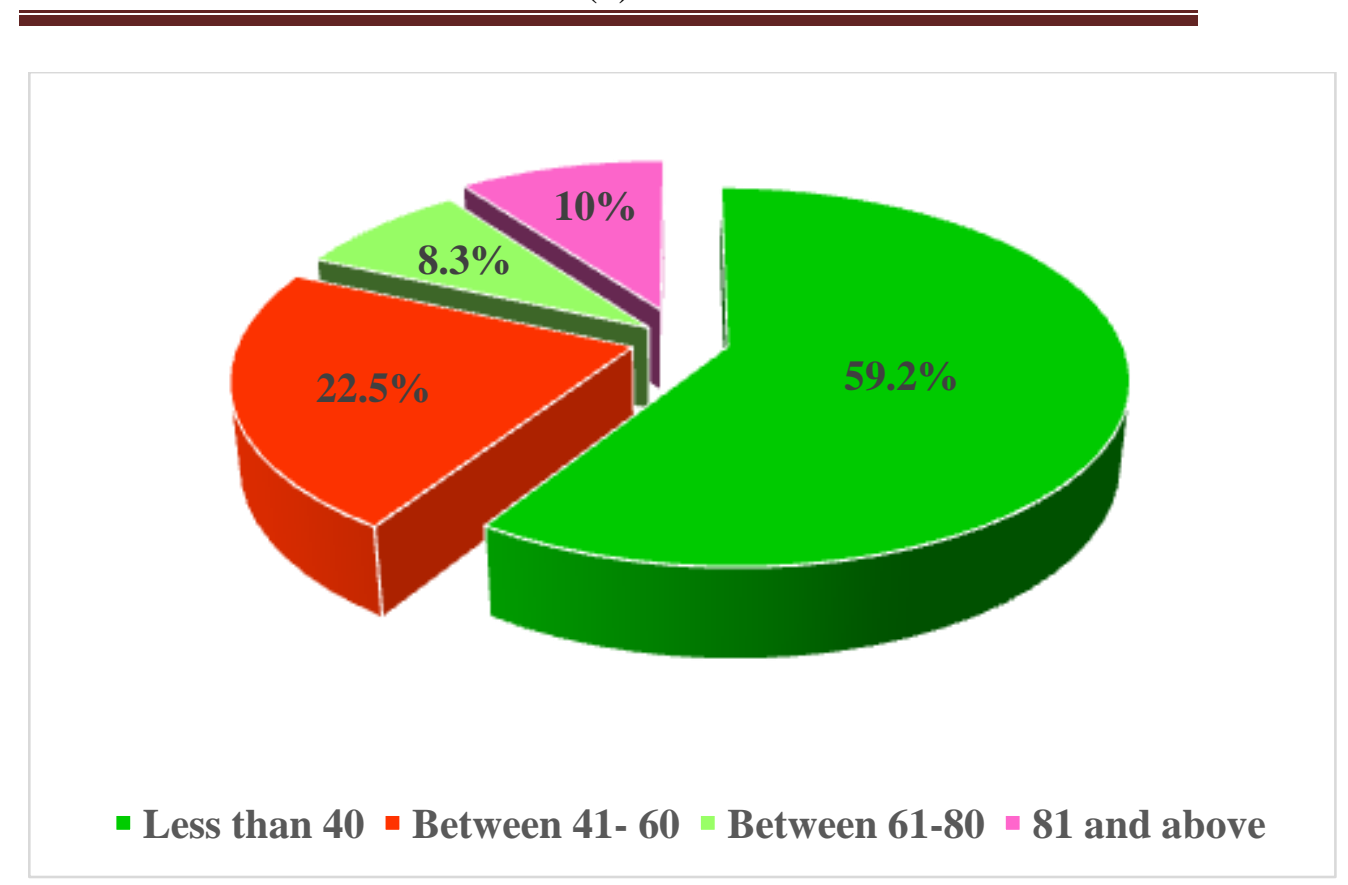

Figure 1: Frequency of overall technical efficiency (CRS) ranges

The following table illustrates the distribution of technical efficiency in terms of CRS, VRS and scale efficiency and its frequencies given in the Table 03.

Table 6: Distribution of DEA technical efficiency ranges

\begin{tabular}{|c|c|c|c|c|c|c|}
\hline \multirow[b]{2}{*}{ Range } & \multicolumn{2}{|c|}{ CRS } & \multicolumn{2}{|c|}{ VRS } & \multicolumn{2}{|c|}{ SE } \\
\hline & 密 & 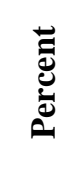 & 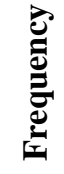 & 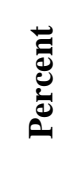 & 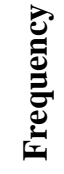 & 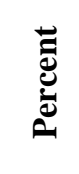 \\
\hline Less than 40 & 71 & 59.2 & 2 & 1.7 & 67 & 55.8 \\
\hline $\begin{array}{l}\text { Between } 41- \\
60\end{array}$ & 27 & 22.5 & 12 & 10.0 & 29 & 24.2 \\
\hline $\begin{array}{ll}\text { Between } & 61- \\
80 & \end{array}$ & 10 & 8.3 & ... & $\cdots$ & 12 & 10.0 \\
\hline 81 and above & 12 & 10.0 & 106 & 88.3 & 12 & 10.0 \\
\hline
\end{tabular}

Source: Authors' calculation using Frontier 4.1, 2020. 
As shown in the above Table, $55.8 \%$ of the farmers belong to the scale efficiency less than $40 \%$ and only $10 \%$ of them attained their VRS efficiency between 41 and 60 , but no one attained this efficiency between 61 and 80 in the study. Nearly $88 \%$ of the farmers attained more than $81 \%$ of VRS efficiency whereas $10 \%$ of them attained CRS and scale efficiencies.

The above results were given in the following figure using bar chart as below.

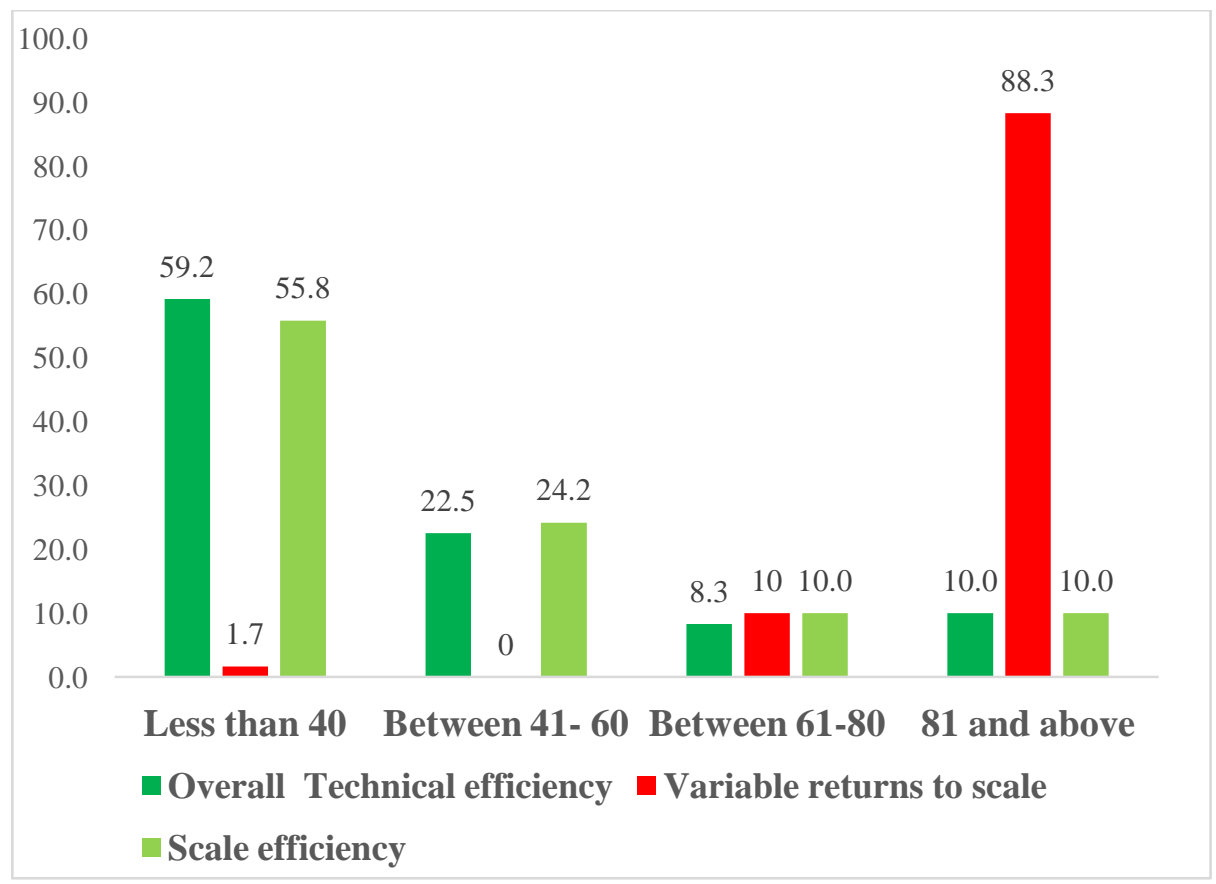

Figure 2: Frequency of all efficiency ranges

The study used input -oriented DEA model for estimating overall technical efficiency ( $\left.\mathrm{TE}_{\mathrm{CRS}}\right)$, pure technical $\left(\mathrm{TE}_{\mathrm{VRS}}\right)$ and scale efficiencies for paddy farms in Mullaitivu district of Sri Lanka. Table 07 represents the mean and standard deviation of the above efficiencies of paddy farms and according to that, on average the overall technical efficiency of paddy farms was nearly $42 \%$, scale efficiency was nearly $45 \%$ and very high VRS technical efficiency was nearly $93 \%$. The result of overall technical efficiency score indicated that the farmers could reduce their use of inputs by almost $58 \%$ and still obtain the same paddy production. Specially, the splitting of the technical 
efficiency measure produced estimates of $7 \%$ of pure technical inefficiency and $55 \%$ scale inefficiency. By eliminating scale inefficiency, farmers can improve their efficiency score from $42 \%$ to $93 \%$.

Table 7: Descriptive statistics of the efficiency

\begin{tabular}{|l|l|l|l|l|}
\hline \multicolumn{1}{|c|}{ Efficiency } & Mean & \multicolumn{1}{c|}{$\begin{array}{c}\text { Standard } \\
\text { deviation }\end{array}$} & Minimum & \multicolumn{1}{c|}{ Maximum } \\
\hline $\begin{array}{l}\text { Overall technical } \\
\text { efficiency }\end{array}$ & 41.90 & 22.19 & 11.30 & 100.00 \\
\hline VRS technical efficiency & 92.80 & 14.72 & 0.00 & 100.00 \\
\hline Scale efficiency & 45.20 & 22.95 & 11.30 & 100.00 \\
\hline
\end{tabular}

Source: Authors' calculation using Frontier 4.1, 2020.

Scale efficiency indicates whether any efficiency can be obtained by improving the size of the operation and the scale efficiency is low with an average of $45 \%$ indicating that the majority of the paddy farmers are operating far from their optimal size. Thus, a low level of scale efficiency represents a high scope for improvement in farm size to increase the efficiencies. It can be seen that scale efficiency was relatively low $(45.2 \%)$ and only $12 \%$ of them achieved scale efficiency $81 \%$ and above showing that most of these farmers were operating very far from the optimal size. Compared to the overall and scale efficiencies, pure technical efficiency $\left(\mathrm{VRS}_{\mathrm{TE}}\right)$ was relatively high suggest that main cause of low technical efficiency for paddy farmers is scale efficiency. In general, the cause of inefficiency may have been either inappropriate scale or misallocation of resources.
Inappropriate scale suggests that the farm is not taking advantage of economies of scale whereas misallocation of resources refers to inefficient of input combinations. In this study, pure technical efficiency was relatively high, but scale efficiency was low proves that efficiencies were mainly due to the inappropriate scale than improper input used (Oren and Alemdar, 2006).

\subsubsection{Returns to scale of sampled farmers}

In addition to analysing the extent of efficiencies or paddy cultivators, it is also very important to identify the distribution of paddy cultivators to fall in three stages of production frontier.

Differences in returns to scale of paddy farmers are shown different returns to scale characteristics as shown in Table 08 . 
Table 8: Returns to scale of the farmers

\begin{tabular}{|l|l|l|}
\hline \multicolumn{1}{|c|}{ Returns to scale } & \multicolumn{1}{|c|}{$\begin{array}{c}\text { Number of } \\
\text { farmers }\end{array}$} & Percentage of the farmers \\
\hline Increasing returns & 112 & 93.3 \\
\hline Decreasing returns & 01 & 0.8 \\
\hline Constant returns & 07 & 5.8 \\
\hline
\end{tabular}

Source: Authors' calculation using Frontier 4.1, 2020.

Out of 120 farmers, 112 of them $(93.3 \%)$ were found to be operating at increasing returns to scale implies that paddy output is increasing by more than the proportional change in the inputs used in the study (Table 8). It means that most of the paddy cultivators were operating in sub - optimal region of the production frontier. Only $0.8 \%$ of the farmers are producing paddy at decreasing returns to scale, indicating that their paddy output increases by less than proportional change in inputs. Since $0.8 \%$ of the paddy cultivators were operating pre optimal region of the production frontier described that, the situation of paddy farmers cultivating their paddy below the optimal scale of production. Remaining $5.8 \%$ of proportionally increasing with the increasing paddy inputs where those farmers are in the optimal region of production frontier.

Table 9: Results of independent samples $t$-test

\begin{tabular}{|c|l|l|l|}
\hline \multirow{2}{*}{ Variables } & \multicolumn{3}{|c|}{ Mean } \\
\cline { 2 - 4 } & $\begin{array}{c}\text { Overall technical } \\
\text { efficiency }\end{array}$ & $\begin{array}{c}\text { VRS technical } \\
\text { efficiency }\end{array}$ & $\begin{array}{c}\text { Scale } \\
\text { efficiency }\end{array}$ \\
\hline Gender & & & \\
\hline Male & 43.39 & 40.70 & 90.87 \\
\hline Female & 46.57 & 43.02 & 91.41 \\
\hline $\begin{array}{l}\text { Ownership of } \\
\text { land**(a) }\end{array}$ & & & \\
\hline Own & 49.59 & 46.60 & 94.11 \\
\hline Tenant & 38.07 & 34.75 & 86.68 \\
\hline Training ${ }^{* * * *(b)}$ & & & \\
\hline Yes & 49.94 & 46.46 & 91.36 \\
\hline No & 38.27 & 35.64 & 90.84 \\
\hline
\end{tabular}


Thayaparan A, \& Neruja N., Wayamba Journal of Management 12 (1)

\begin{tabular}{|c|l|l|l|}
\hline Extension & & & \\
\hline Yes & 46.01 & 43.36 & 90.80 \\
\hline No & 44.11 & 40.59 & 91.42 \\
\hline Credit & & & \\
\hline Yes & 44.25 & 40.89 & 90.66 \\
\hline No & 46.00 & 43.20 & 91.81 \\
\hline Land quality $^{* * *(c)}$ & & & \\
\hline Yes & 64.33 & 61.04 & 93.60 \\
\hline No & 40.14 & 37.06 & 90.52 \\
\hline Destroy ${ }^{* *(d)}$ & & & \\
\hline Yes & 43.95 & 41.45 & 93.40 \\
\hline No & 47.21 & 42.75 & 86.27 \\
\hline
\end{tabular}

Note: *** and $* *$ represents $1 \%, 5 \%$ significant levels respectively.

(a) Represents ownership of land is significant for all three efficiencies.

(b) Represents training is significant only for all overall $\mathrm{TE}$ and scale efficiencies.

(c) Represents land quality is significant only for all overall TE and scale efficiencies.

(d) Represents destroy is significant only for VRS technical efficiency.

The slack of inputs variables in terms of mean were illustrated in Table 10 and according to that, cost of capital has the highest slack followed by costs of labour and fertilizer. Among them, seed cost has less slack which means that most of the seed were used in the farming and they need to pay additional cost when they purchase additional seed. 
Table 10: Slack of inputs variables

\begin{tabular}{|l|r|}
\hline \multicolumn{1}{|c|}{ Variables } & \multicolumn{2}{|c|}{ Mean slack } \\
\hline Cost of labour (Rs) & 366.81 \\
Cost of capital (Rs) & 816.24 \\
Machinery cost (Rs) & 163.36 \\
Cost of seed (Rs) & 45.09 \\
Fertilizer cost (Rs) & 225.40 \\
Cost of pesticide & 156.73 \\
Size of land & 156.28 \\
\hline
\end{tabular}

Source: Authors' calculation using Frontier 4.1, 2020.

The results further explained that, a farmer can reduce the above costs of inputs by their slack quantities without decreasing the existing output to become efficient. As the overall technical efficiency score measured as $42 \%$ further reveals that, there is a need to reduce the above cost of inputs by $58 \%$ to attain the efficiency in paddy farming.

\subsection{Results of Tobit model: Factors affecting VRS-DEA technical efficiency}

The estimated results of the Tobit regression coefficients and average marginal effects of three explanatory variables on the components of technical efficiency such as technical efficiency, pure technical efficiency and scale efficiency are shown in Table 11. The overall technical efficiency, pure technical efficiency and scale efficiency were taken as three dependent variables separately which are regressed on demographic and farming characters in the Tobit model. The overall significance of the Tobit model can be tested using Pseudo $\mathrm{R}^{2}$ value and it is significant at $1 \%$ and $5 \%$ levels implies that to explain the impact of selected demographic and farming characters on overall technical efficiency, pure technical efficiency and scale efficiency, the estimated Tobit model is adequate one.The results show that, education, land ownership, amount of savings, loan size, land quality and farm income were found to have positively significant impact on overall technical efficiency while experience, ownership of land, amount of savings and destroy of the land significantly influenced on pure technical efficiency in the study. On the other hand, scale efficiency of paddy farming mostly influenced by education, ownership of land, saving amount, loan size, quality of land and farm income. 
Thayaparan A, \& Neruja N., Wayamba Journal of Management 12 (1)

Table 11: Results of Tobit model in determining efficiencies

\begin{tabular}{|c|c|c|c|c|c|c|}
\hline \multirow[b]{2}{*}{ Variables } & \multicolumn{2}{|c|}{$\begin{array}{c}\text { Overall technical } \\
\text { efficiency }\end{array}$} & \multicolumn{2}{|c|}{$\begin{array}{c}\text { Pure technical } \\
\text { efficiency }\end{array}$} & \multicolumn{2}{|c|}{ Scale efficiency } \\
\hline & ن⿺辶ِّ & 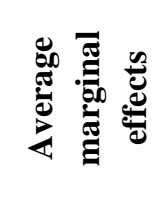 & ن & 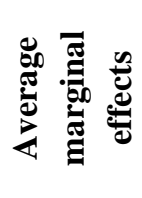 & U⿺辶ِّ & 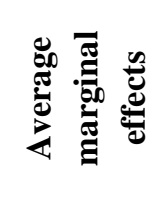 \\
\hline Education & $\begin{array}{l}1.483^{* *} \\
(.615)\end{array}$ & 0.315 & $\begin{array}{l}-0.450 \\
(.501)\end{array}$ & -0.039 & $\begin{array}{l}1.612^{* *} \\
(.641)\end{array}$ & 0.315 \\
\hline Experience & $\begin{array}{l}-0.163 \\
(.178)\end{array}$ & -0.087 & $\begin{array}{l}-0.356^{* *} \\
(0.145)\end{array}$ & -0.076 & $\begin{array}{l}-0.147 \\
(.186)\end{array}$ & -0.072 \\
\hline Family size & $\begin{array}{l}1.002 \\
(1.22)\end{array}$ & 0.114 & $\begin{array}{l}0.121 \\
(0.999)\end{array}$ & 0.005 & $\begin{array}{l}1.283 \\
(1.28)\end{array}$ & 0.134 \\
\hline Gender & $\begin{array}{l}-2.902 \\
(3.29)\end{array}$ & -0.041 & $\begin{array}{l}0.459 \\
(2.684)\end{array}$ & 0.002 & $\begin{array}{l}-3.812 \\
(3.43)\end{array}$ & -0.05 \\
\hline $\begin{array}{l}\text { Land } \\
\text { ownership }\end{array}$ & $\begin{array}{l}9.042^{m+m} \\
(3.22)\end{array}$ & 0.130 & $\begin{array}{l}5.508^{* i n} \\
(2.62)\end{array}$ & 0.035 & $\begin{array}{l}8.887^{7 * 4} \\
(3.36)\end{array}$ & 0.119 \\
\hline Training & $\begin{array}{l}-4.257 \\
(3.85)\end{array}$ & -0.060 & $\begin{array}{l}1.465 \\
(3.13)\end{array}$ & 0.009 & $\begin{array}{l}-4.496 \\
(4.02)\end{array}$ & -0.058 \\
\hline Extension & $\begin{array}{l}2.101 \\
(3.17)\end{array}$ & 0.025 & $\begin{array}{l}-1.186 \\
(2.58)\end{array}$ & -0.006 & $\begin{array}{l}1.394 \\
(3.30)\end{array}$ & 0.015 \\
\hline Saving & $\begin{array}{l}0.003^{* * a} \\
(0.001)\end{array}$ & 0.109 & $\begin{array}{l}-0.002^{* ; *} \\
(0.001)\end{array}$ & -0.029 & $\begin{array}{l}0.003^{*} \\
(0.001)\end{array}$ & 0.108 \\
\hline Loan size & $\begin{array}{l}0.00003 \\
{ }_{* * * *}(5.93 \\
e-06)\end{array}$ & 0.141 & $\begin{array}{l}-3.45 e- \\
07 \\
(4.83 e- \\
06)\end{array}$ & -0.0008 & $\begin{array}{l}0.00003^{* 3 * *} \\
(6.18 \mathrm{e}-06)\end{array}$ & 0.132 \\
\hline $\begin{array}{l}\text { Land } \\
\text { quality }\end{array}$ & $\begin{array}{l}14.992^{*} \\
{ }_{* *}(5.08)\end{array}$ & 0.050 & $\begin{array}{l}4.903 \\
(4.14)\end{array}$ & 0.010 & $\begin{array}{l}13.763^{* *} \\
(5.30)\end{array}$ & 0.044 \\
\hline $\begin{array}{l}\text { Farm } \\
\text { income }\end{array}$ & $\begin{array}{l}0.0017^{*} \\
{ }_{* *}^{*} \\
(0.0006 \\
)\end{array}$ & 0.369 & $\begin{array}{l}0.00002 \\
(0.0005 \\
)\end{array}$ & 0.001 & $\begin{array}{l}0.002^{* * *} \\
(0.0006)\end{array}$ & 0.386 \\
\hline Destroy & $\begin{array}{l}0.353 \\
(3.275)\end{array}$ & 0.006 & $\begin{array}{l}6.607^{* 2} \\
(2.66)\end{array}$ & 0.048 & $\begin{array}{l}-1.472 \\
(3.41)\end{array}$ & -0.026 \\
\hline $\begin{array}{l}\text { Constant } \\
\text { Pseudo } \mathrm{R}^{2} \\
\text { LR Chi }\end{array}$ & $\begin{array}{l}-2.66 \\
(10.1) \\
0.070^{* * *}\end{array}$ & & $\begin{array}{l}94.06 \\
(8.22) \\
0.030^{* *}\end{array}$ & & $\begin{array}{l}- \\
1.931(10.52) \\
0.068^{* * * *}\end{array}$ & \\
\hline
\end{tabular}




\begin{tabular}{|c|c|c|c|}
\hline $\begin{array}{l}\text { square } \\
\text { Log } \\
\text { likelihood }\end{array}$ & $\begin{array}{l}76.15 \\
-501.17\end{array}$ & $\begin{array}{l}29.41 \\
-476.08\end{array}$ & $\begin{array}{l}74.46 \\
-506.11\end{array}$ \\
\hline
\end{tabular}

Source: Authors' calculation using Stata 13, 2020.

Note: $* * *$ and $* *$ represents $1 \%$ and $5 \%$ levels of significant respectively.

Standard errors are in the parentheses.

The coefficient of education was positive and significant at $5 \%$ level on both overall and scale efficiency which is the expected result confirming the important role of education in efficiency improvements. This results suggests that, paddy farmers with higher education level tend to attain higher technical efficiency in their farming. The findings of this study was consistent with the findings illustrated by Tien, Thong (2014) and Shamsudin (2014). Further, the farmers who are more educated expected to have a better understanding of modern technologies which often tend to have better managerial expertise and thus they are more likely to be efficient than less educated farmers. The coefficient of average marginal effect for education was found to be 0.315 with positive sign on both overall technical efficiency and scale efficiency revels that as farmers' education increases by one more year, those efficiencies would increase by $31.5 \%$. The above findings summarized that, ownership of land and amount of saving are the major three factors determine all three efficiency levels whereas destroy of land only significant on pure technical efficiency in the study.

Experience in farming has negative sign in pure technical efficiency shows that, as framers' experience in farming increases by one more year, would reduce the pure efficiency and its average marginal effect suggest that, the pure technical efficiency will reduce by $7.6 \%$. Although, faming experience was insignificant in other two efficiencies in the study. This result contradicted with the earlier studies done by Umar Mukhtaret al, (2018). Another farming character is the ownership of land whether the farmers are cultivating the paddy on their own land or tenant positively influencing all three efficiency scores at $1 \%$ and \% significant levels. This means that, own land farmers are more technically efficient in terms of overall, pure and scale than tenant farmers in the study. The farmers who have cultivating paddy in their own land, will motivate them to adopt new farm management practices and techniques for increase their efficiency compared to the tenant cultivators. The average marginal 
effects for overall technical efficiency is 0.130 while pure technical efficiency and scale efficiency have 0.035 and 0.119 respectively implies that, the farmers who have own land in their paddy farming, overall technical efficiency will increase by $13 \%$, pure and scale efficiencies will increase by $3.5 \%$ and $11.9 \%$ respectively. These results are opposite to those reported by Shamsheerul and IsmetBoz (2019) which indicated that rented land rice farmers have higher technical efficiency than leased or own land farmers in the study. The farmers who have more savings, their overall technical efficiency and scale efficiency will be more and pure efficiency will be lower that the farmers who have less saving in the study. Because, saving is the major financial tool for increasing the efficiency of paddy farms by adopting new production techniques in farming. The coefficient of loan size has positively significant impact on overall technical efficiency and scale efficiency and their average effects have 0.141 and 0.132 . It reveals that as loan size increases overall technical efficiency and scale efficiency score will be increased by $14.1 \%$ and $13.2 \%$ respectively. However, pure technical efficiency not influenced by the loan size in the study. Land quality and farm income also positively significant impact on overall and scale efficiencies but it is insignificant in pure technical efficiency in the model indicates that the farmers who maintain their land quality and who earns more income from farming, their efficiency will be more than their counterparts. Finally, the coefficient of destroy has positive impact on pure technical efficiency at 5\% level and it was not significant in other two efficiencies in the study.

\section{CONCLUSION}

In this study, technical efficiency and its decompositions were estimated using non - parametric approach among 200 selected paddy farmers in Mullaitivu district. Two analytical tools under non - parametric approaches namely Hicks Moorsteen total factor productivity index and two stage input-oriented data envelopment were employed in the study. Results derived from Hicks - Moorsteen index suggested that among the components of Hicks Moorsteen index, $94 \%$ of the highest mean value was attained in ITE followed by $93 \%$ of efficiency was attained in OSE. On average, $56 \%$ of efficiency was recorded in TFPE followed by $59 \%$ of efficiency attained in RISE and ISME.Tobit model was applied to examine the impact ofdemographic, economic, farming and environmental factors on total factor productive efficiency index and its results revealed that education, training and crop destruction due to changes in climate were 
significant whereas farm experience, amount of saving, loan amount and income earns from farming were significant influence on total factor productive efficiency at $5 \%$ and $10 \%$ levels respectively. Rest of other variables were not significant in the model to explain the total factor productive efficiency of paddy farms in the study area.

In addition to the Hicks Moorsteen total factor productivity approach, two stage DEA also applied to estimate the technical efficiency and explore the factors influencing the efficiency of paddy farmers in the study. The estimated results indicate that on average the overall technical efficiency of paddy farms was nearly $42 \%$ indicated that the farmers could reduce their use of inputs by almost $58 \%$ and still obtaining the same paddy production. Specially, the farmers could improve their efficiency from $42 \%$ to $93 \%$ by eliminating their scale inefficiency. Estimated results of Tobit model showed that both overall technical efficiency and scale efficiency positively influenced by education of the farmer while experience in farming positively impact on pure technical efficiency. Also, land ownership has a positive impact on overall technical efficiency, pure technical efficiency and scale efficiency in the study.

\section{REFERENCES}

Amaechi E. C. C.J. E. Ewuziem and M. U. Agunanna. (2014). Estimation of technical efficiency in the translog stochastic frontier production function model: An application to the oil palm produce mills industry in Nigeria. Advances in Applied Science Research, 3(5), 230-236.

Bjurek, H. (1996). 'The Malmquist total factor productivity index'. The Scandinavian Journal of Economics, 303-313.

Central Bank of Sri Lanka. (2019). Central Bank of Sri Lanka Annual Report. Colombo: Central Bank of Sri Lanka.

Coelli, T.J., D.S.P. Rao, C.J. O'Donnell and G.E. Battese. (2005). 'An introduction to effi ciency and productivity analysis'. Springer-er Science and Business Media. 
Diewert, W. Erwin. (1992). "Fisher ideal output, input, and productivity indexes revisited.". Journal of Productivity Analysis, 3(3), 211-248.

District Secretariat. (2019). Statistical Hand book, Mullaitivu: District Secretariat, Sri Lanka.

KHAILE, P.M.E. (2012). Factors Affecting Technical Efficiency of Small-Scale Raisin Producers in Eksteenskuil. Thesis, University of the Free State, Department of Agricultural Economics, Bloemfontein.

Linh, L.T. Lee, P.P. Peng, C.K and Chung,R.H. (2017). Factors Influencing Technical Efficiency of Rice Farms in Dong Thap Province, Vietnam: An Application of TwoStage DEA. AmericanEurasian J. Agric. \& Environ. Sci, 3(17), 245249.

Mukhtar, U., Mohamed, Z., Shamsuddin, M.N., Sharifuddin, j and Iliyasu, A. (2018). 'Application of data envelopment analysis for technical effi ciency of smallholder pearl millet farmers in
Kano State, Nigeria'. Bulgarian Journal of Agricultural Science, 2(24), 213-222.

Nemoto, Jiro, and Mika Goto. (2005). Productivity, efficien"scale economies and technical change: A new decomposition analysis of TFP applied to the Japanese prefectures.". Journal of the Japanese and International Economies, 4(19), 617-634.

Nugawela, T.G. (2019). Sri Lanka's Total factor Productivity change during conflict and postconflict periods. 1(49), 1 19.

O’Donnell, C. J. (2011) DPIN 3.0: a program for decomposing productivity index numbers, mimeo, CEPA Working Paper WP07/2011. University of Queensland.

Oren, M.N.and Alemdar, T. (2006). Technical efficiency analysis of tobacco farming in southeastern Anatolia'. Turkish Journal Agricultural Forestry(30), 165-172. 
Peng, J., Wen,L., Fu,L. et al. (2020). 'Total factor productivity of cultivated land use in China under enviornmental constraints: temporal and spatial variations and their influencing factors'. Enviornmental Science pollution reseach 27, 1844318462.

Shamsheer, U.H and Ismet, B. (2020). 'Tea Productivity Analysis and its Determinants:

Implications for Higher Production and Cost Savings with Different Farm Sizes '. Custos e Agronegocio, 16(2), 372391.

Shamsudin, M.N.,. (2014). 'Rice Farms Efficiency and Factors Affecting the Efficiency in MADA Malaysia'. Journal of Applied Sciences, 18(14), 2177-2182.

Shantha, A, Asan Ali, B.G.H and Bandara, R.A.G. (2013). Technical Efficiency Of Paddy Farming Under Major Irrigation Conditions In The DryZone Of Sri Lanka: A Parametric Approach. Australian Journal of
Basic and Applied Sciences , 6(7), 104-112.

Tien, N.V. and Thong, P.L. (2014). 'Analyzing economic efficiency of the lotus farms in Dong Thap Province'. Scientific Journal of Can Tho(30), 120-128. 